\title{
Privacy Issues in Libraries with Online Services: Attitudes and Concerns of Academic Librarians and University Students in Ghana
}

\author{
Bright Kwaku Avuglah, Christopher M. Owusu-Ansah, Gloria \\ Tachie-Donkor, and Eugene Baah Yeboah
}

\begin{abstract}
This study surveyed librarians' and students' attitudes, perceptions, and concerns on privacy in Ghanaian universities with the aim of seeking a better alignment of their perspectives in the online library context. The study adapted and applied the instrument developed by Zimmer that assessed attitudes and practices of librarians in the United States on privacy rights and protecting patrons' privacy in the library. ${ }^{1}$ The study found that, between librarians and students in Ghanaian universities, there was a need for greater control over their personal data and a need for ethical responsibility on the part of data collecting online library agents; both groups expressed dislike for state censorship and corporate monopoly over their personal data. However, despite their positive attitude about the strong role of librarians in guaranteeing their personal data, a significant number of them demonstrate little faith in librarians to actualize the protection of their personal data. Finally, privacy attitudes and concerns of academic librarians were noted to align with those of university students in Ghana. Among others, it was recommended that Ghanaian academic librarians integrate privacy education and awareness creation in their universities, emphasizing the need to make informed online decisions and exposing potential repercussions of their decisions while using online library and digital resources.
\end{abstract}

\section{Introduction}

The issue of patron privacy and confidentiality is core to the ethics, norms, and traditions of libraries. ${ }^{2}$ This is emphasized by a number of professional and international library organizations such as International Federation of Library Associations and Institutions (IFLA) and the African Library and Information Associations and Institutions (AfLIA) through statements and other official instruments. ${ }^{3}$ Libraries have long been involved in promoting and addressing privacy concerns of their patrons even before the digital revolution. ${ }^{4}$ Whether by nondisclosure

Bright Kwaku Avuglah is Principal Library Assistant, University of Ghana; email: bkavuglah@ug.edu.gh.Christopher M. Owusu-Ansah is Senior Assistant Librarian, University of Education, Winneba, Mampong campus; and Research Fellow, Department of Information Science, University of South Africa; email: cmfum@uew.edu.gh. Gloria Tachie-Donkor is Junior Assistant Librarian; email: gtachie-donkor@ucc.edu.gh. Eugene Baah Yeboah is Principal Library Assistant, University of Cape Coast; email: eugene.yeboah@ucc.edu.gh. (02020 Bright Kwaku Avuglah, Christopher M. Owusu-Ansah, Gloria Tachie-Donkor, and Eugene Baah Yeboah, Attribution-NonCommercial (https://creativecommons.org/licenses/by-nc/4.0/) CC BY-NC. 
of borrowers' identities, ${ }^{5}$ or short-term data retention policies and anonymous browsing of its collections, ${ }^{6}$ libraries assert their role as vital institutions that guarantee the right to freedom of thought and expression in and toward a free society. ${ }^{7}$ Tummon and McKinnon note that, even in the face of the rapidly evolving digital landscape where the blurring of boundaries of acceptable information-sharing practices makes data and privacy protection extremely complicated, ${ }^{8}$ libraries and librarians maintain their advocacy for privacy as a sacred and inalienable right of patrons, reinforcing their position as privacy champions. ${ }^{9}$

This descriptive survey tracks the alignment between the attitudes, perceptions, and concerns of academic librarians and university students on privacy from the perspective of three top Ghanaian universities, namely the University of Ghana (UG), the University of Cape Coast (UCC), and the University of Education, Winneba (UEW). Drawing on empirical evidence, this study extends our understanding on privacy and confidentiality in the worldviews of both librarians and students from a unique African cultural perspective, given that the concept of privacy was often a Western mantra. ${ }^{10}$

\section{Literature Review}

Many modern libraries endeavor to incorporate a number of technology tools and services into their operations to improve work efficiency, service delivery, and user experience. These technologies range from commercial and open access academic databases, other research tools such as reference managers and plagiarism software, and Web 2.0 tools and applications such as Social Networking Sites (SNS), video-sharing sites, wikis, blogs, chats, and folksonomies. Many of these technologies have the capability to aggregate users' personal information and feedback and track online behaviors. ${ }^{11}$ Despite the numerous benefits and possibilities that this affords, ${ }^{12}$ a new conundrum arises in balancing the benefits with the privacy consequences they pose for both librarians and their patrons. ${ }^{13}$

As a point of departure, systems for safeguarding data and information exchanges over these platforms by the library and their users are not controlled by the library but by thirdparty partners and institutions whose business models revolve around the wealth of personal details in their custody, ${ }^{14}$ and what they do with that wealth of data is not exactly known to the library. Seemingly innocuous and vague information shared by or about users can be mapped to other anonymized data from other sources to reidentify and create a story around and about the users ${ }^{15}$ in terms of their intellectual activities, online behaviors, interests, and tendencies or even track their physical movement. ${ }^{16}$ Givens notes that such surveillance, no matter how harmless it appears, is a breach of privacy that can impede the free exchange of ideas, hinder information seeking, critical thinking, and the development of new ideas and opinions. ${ }^{17}$

Previous studies about online privacy issues in the library show a growing interest in privacy rights and patron data confidentiality. ${ }^{18}$ Attitudinal studies on the subject, though very few, have sought to explore the perspective of both librarians and their student users. For instance, the studies conducted by Tummon and McKinnon in Canada and Zimmer in the United States found that librarians were very concerned about online and patron privacy and that they recognize the need for protecting and educating their patrons as an imperative responsibility. Farkas noted that this educational role of librarians is extremely valuable especially for younger patrons who often do not appreciate the long-term implications of careless information-sharing practices online.$^{19}$ Unlike their American counterparts, however, most 
Canadian librarians lack knowledge about their own institutional policies and procedures and are not confident that they are doing their very best in protecting patron privacy. ${ }^{20}$

When Johns and Lawson surveyed undergraduate students about their knowledge and perceptions of online privacy issues in 2005 at Iowa State University (ISU), they found that the students considered online privacy to be very important to them as well. They expected the library to only collect their personal data with their consent and with a clearly defined purpose and life span. They also did not want the library to share their personal information without their knowledge and expected the library to educate them about privacy issues, even though, regrettably, the library was not proactive in carrying out this responsibility. ${ }^{21}$

Siemens, Althaus, and Stange studied students' perceptions of privacy within the context of e-learning environments. ${ }^{22}$ Their results show that students had concerns about sharing too much information about themselves on such platforms and feared their opinions might be misrepresented. Students also lacked adequate knowledge about privacy issues including their institutional policies and legal obligations regarding the privacy, confidentiality, and security of students' personal data but are unlikely to read these policies even if they were made readily available to them. This last point is symptomatic of the privacy paradox phenomenon $-\mathrm{a}$ discrepancy between privacy attitudes and behaviors - where people express concerns about their privacy yet undertake very little action to protect their personal data. ${ }^{23}$

Overall, the sentiments students expressed in both studies resonate with those from librarians: however, the palpable gaps in librarians' own practices and the perceptions of students about their libraries' support is instructive. These studies were carried out in different locations and timelines and do not provide the strongest picture on privacy attitudes, concerns, and practices in any of the study locations. Combining the opinions of both librarians and the students they serve within the same study will provide a fairer picture of the current state of affairs and better alignment between recommended strategies for libraries and user needs.

\section{Problem Statement}

Compared to developed regions, studies on privacy attitudes and concerns within the library and information science (LIS) landscape in Africa and Ghana particularly are very scarce. Even in the developed regions, such studies focused on either librarians ${ }^{24}$ or users. ${ }^{25}$ Our search of the literature did not reveal any studies that have examined the attitudes, perceptions, and concerns of both librarians and user communities within the same study, which might yield better alignment between recommended strategies for libraries and user needs. This study focuses on the alignment issues by comparing data on librarians' attitudes and concerns to those of their users. The insight gained from this study can raise awareness about such misalignment for practitioners to proffer solutions that are fit for purpose.

Furthermore, while the studies by Zimmer and Tummon and McKinnon are great attempts to gauge librarians' practices and attitudes on issues of privacy in online library environments, Jeske, Intahchomphoo, Landriault, and Bioni asserted that such practices and attitudes are susceptible to cultural differences, as was confirmed in both studies. ${ }^{26}$ For instance, Ghana's data protection laws and the LIS landscape are generally different from what persists in most developed countries. Understanding the attitudes and practices of librarians in Ghana alongside their user communities can help contextualize the role of libraries in protecting patron privacy and promoting privacy literacy among their users. The outcome of this study can 
provide guidance for developing library policies, guidelines, and training programs toward improving patrons' privacy literacy and informed online decisions. ${ }^{27}$

To this end, the purpose of this study was to explore the attitudes and concerns on privacy issues in Ghanaian academic and research library space. The specific objectives of the study, and associated hypotheses, were to:

1. Assess the attitudes of Ghanaian librarians and university students toward the issue of privacy in online library environments.

2. Identify the concerns of Ghanaian librarians and university students about privacy in online library environments.

3. Explore any differences in attitudes and concerns between Ghanaian librarians and university students.

3.1. $\mathbf{H}_{1}$ There are no significant differences in the privacy attitudes and concerns of librarians and students.

$\mathbf{H}_{\mathbf{0}}$ There are significant differences in the privacy attitudes and concerns of librarians and students.

\section{Methods and Instruments}

This study constituted a survey, and the data collection instrument used was adapted from the study by Zimmer that assessed attitudes and practices of librarians in the United States on privacy rights and protecting patrons' privacy in the library. ${ }^{28}$ To ascertain the reliability of the instrument, two steps were taken. First, the questions were adapted to the Ghanaian context by expunging questions relating to the legal system of the United States. Some of the questions on general attitudes and concerns were also excluded. A few new questions were added to cater for local context, and some questions were also modified. Where a new question was added, these were marked by a plus $(+)$, with modified questions in the original instrument marked with an asterisk $\left(^{*}\right)$. Second, the questionnaire was then pretested in two of the public universities, with a total of 20 respondents comprising 15 students and 5 librarians. Feedback from the pretest was incorporated into the final questionnaire.

The resulting questionnaire comprised nine close-ended questions. The questionnaire was in three sections. Section A comprised demographics (see table 2); Section B, respondents' general attitudes to privacy in online environments (see table 5); and Section C, respondents' concerns with privacy in online environments (see table 6).

Respondents were limited to only three major public universities in Ghana. These are as follows: University of Cape Coast (UCC), University of Education, Winneba (UEW), and University of Ghana (UG). The institutions included in this study had libraries with an online presence.

\begin{tabular}{|l|l|c|c|c|c|c|}
\hline \multicolumn{7}{|c|}{ TABLE 1 } \\
Response Rate of Students \\
\hline Institution & $\begin{array}{l}\text { Student } \\
\text { Population }\end{array}$ & $\begin{array}{l}\text { Sample } \\
\text { Size }\end{array}$ & $\begin{array}{l}\text { Returned } \\
\text { Questionnaire }\end{array}$ & Invalid & $\begin{array}{l}\text { Valid } \\
\text { Questionnaires }\end{array}$ & $\begin{array}{l}\text { Valid Response } \\
\text { Rate (\%) }\end{array}$ \\
\hline UG & 38,000 & 381 & 289 & 3 & 286 & $\mathbf{7 5}$ \\
\hline UCC & 74,720 & 383 & 181 & 3 & 178 & $\mathbf{4 6 . 5}$ \\
\hline UEW & 61,711 & 382 & 282 & 20 & 262 & $\mathbf{6 8 . 6}$ \\
\hline Total & $\mathbf{1 7 4 , 4 3 1}$ & $\mathbf{1 , 1 4 6}$ & $\mathbf{7 5 2}$ & $\mathbf{2 6}$ & $\mathbf{7 2 6}$ & $\mathbf{6 3 . 4}$ \\
\hline
\end{tabular}


The survey was conducted during the period of January 15, 2019, and March 30, 2019. The survey was administered in-person to respondents across the three university campuses. A nonprobability convenience sampling method was used to recruit respondents for the study. A sample calculator was used to determine the sample size of the studentrespondents, and a self-selective method was used to recruit librarian-respondents across the three institutions.

In all, 74 librarians and 752 students responded to the questionnaire across the three institutions surveyed. In 26 cases of the student responses, a significant portion of the questionnaire was left unanswered; as a result, these were excluded, culminating in a final valid response of 726 for students. This yielded a response rate of 63.4 percent for students (see table 1).

\section{Method of Data Analysis}

The data was coded and entered into SPSS 24 for analysis. For the sections on education, some respondents wrote Degree or HND as "Other" level of education, even though these had been catered for in the response options. To standardize the data, we input the appropriate level of education instead of "Other." Descriptive statistics and Mann-Whitney U Test were run on the data to ascertain privacy attitudes and concerns of librarians and students, including whether or not there were significant differences in the pattern of responses of the two groups of respondents.

\section{Results}

\section{Demographics}

The demographic data as presented in table 2 shows that most of the librarians who responded to the questionnaire worked in the Collection and Technical Services (35.1\%), Public Services $(33.8 \%)$, and Digital Initiatives $(14.9 \%)$ sections of the libraries. Members of staff in these units provide some services over online systems and electronic platforms and their perception, attitude, and concerns about privacy can influence their practice of protecting patron privacy. A majority of them were senior staff $(51.4 \%)$, and the fewest were senior members (17.6\%). Employees in public universities in Ghana fall under one of three categories: senior members - a management/professional level role with a minimum qualification of master's degree in LIS; senior staff - a paraprofessional/middle-level role that also requires a universitylevel diploma or a bachelor's/honors degree in LIS; junior staff-a clerical/support role with educational qualification lower than a university-level diploma.

\begin{tabular}{|l|c|c|}
\hline \multicolumn{1}{|c|}{$\begin{array}{c}\text { TABLE 2 } \\
\text { Demographic Data }\end{array}$} \\
\hline \multicolumn{1}{|c|}{ Librarians (N= 74) } & n \\
\hline Job Description & 9 & 12.2 \\
\hline Administration & 25 & 33.8 \\
\hline Public Services (Liaison/Subject Specialist/Reference/Instruction) & 26 & 35.1 \\
\hline Collection and Technical Services (Acquisitions/Cataloguing/e-Resources/Systems) & 11 & 14.9 \\
\hline Digital Initiatives (Digitization/Scholarly Communications/User Experience) & 3 & 4.1 \\
\hline Archives/Special Collections & \\
\hline Rank & 23 & 31.1 \\
\hline Junior Staff
\end{tabular}




\begin{tabular}{|c|c|c|}
\hline \multicolumn{3}{|c|}{$\begin{array}{c}\text { TABLE } 2 \\
\text { Demographic Data }\end{array}$} \\
\hline Senior Staff & 38 & 51.4 \\
\hline Senior Member & 13 & 17.6 \\
\hline \multicolumn{3}{|l|}{ Level of Experience } \\
\hline Less than 1 year & 13 & 17.6 \\
\hline $1-5$ years & 12 & 16.2 \\
\hline $6-10$ years & 22 & 29.7 \\
\hline $11-15$ years & 11 & 14.9 \\
\hline More than 15 years & 16 & 21.6 \\
\hline \multicolumn{3}{|l|}{ Educational Level } \\
\hline $\mathrm{PhD}$ & 6 & 8.1 \\
\hline MPhil/Master's & 23 & 31.1 \\
\hline Bachelor's Degree & 31 & 41.9 \\
\hline HND/Diploma & 9 & 12.2 \\
\hline WASSCE/SSSCE/BECE & 3 & 4.1 \\
\hline Other & 2 & 2.7 \\
\hline \multicolumn{3}{|c|}{ Students $(N=726)$} \\
\hline \multicolumn{3}{|l|}{ Educational Level } \\
\hline Undergraduate (Diploma/Bachelor's) & 626 & 86.2 \\
\hline Graduate (MA/MSc/MPhil) & 68 & 9.4 \\
\hline Postgraduate (PhD) & 27 & 3.7 \\
\hline Other & 5 & .7 \\
\hline
\end{tabular}

In terms of experience, most of them had been practising librarians for more than 5 years $(66.2 \%)$. The education background distribution of the librarians are as follows: 6 of them had a PhD, 23 had an MPhil or master's, 31 indicated they had a bachelor's degree, 9 had a Higher National Diploma (HND) or an ordinary diploma, 3 had the West African Senior Secondary Certificate Examination (WASSCE; formerly known as the Senior Secondary School Certificate Examination [SSSCE], a standard test for Senior High Schools in Ghana and a prerequisite for entry into universities and colleges), or the Basic Education Certificate Examination (BECE: also a standard test for junior high school students in Ghana and a prerequisite for entry into a senior high or vocational school in Ghana), while two respondents indicated "Other" but did not indicate what qualification they had. Also, a majority of the students who responded to the questionnaire were undergraduate students (86.2\%): 9.4 percent of them were studying for a master's degree and 3.7 percent of them were studying for a PhD. Less than 1 percent of the students indicated "Other" for their level of education but did not indicate the level of education they had.

\section{Attitudes toward Online Library Privacy}

The detailed results on general privacy attitudes of librarians and students are presented as a comparative table in the appendices (see table 5). The analysis indicates that most of the respondents (75.7\% of librarians and $86.5 \%$ of students) agree or strongly agree that individuals 
should be able to control who sees their personal information, and half of the respondents ( $50 \%$ of librarians and $50.4 \%$ of students) agree or strongly agree that third-party firms are collecting too much personal information in online library environments. A majority of the respondents (71.6\% of librarians and $80.9 \%$ of students) agree or strongly agree that libraries should never share personal information, circulation records, or internet use records with third parties unless it was authorized by the individual or by the court. Similarly, 81.1 percent of librarians and 85.2 percent of students agree or strongly agree that, when people give their personal information to a company for a specific purpose, the company should only use the information for that purpose. Just over half of the respondents (52.7\% of librarians and $54.4 \%$ of students) agree or strongly agree that librarians are doing all they can to prevent unauthorized access to students' personal information and circulation records. Respondents also showed a positive attitude toward the role of libraries in privacy education. Most of the respondents (77\% of librarians and $83.8 \%$ of students) agree or strongly agree that librarians should play a role in educating students on the potential privacy rights risks resulting from using the internet.

Again, most of the respondents ( $74.3 \%$ of librarians and $80.8 \%$ of students) agree or strongly agree that search engines and social networking sites should prominently display policies on how a user's information is treated. Also, 50 percent of librarians and 46.4 percent of students agree or strongly agree that search engines are sharing their personal information and search records with companies, and 28.4 percent of librarians and 27.8 percent of students disagree or strongly disagree with this statement. Only 18.9 percent of librarians and 31.5 percent of students agree or strongly agree that they don't mind if the government knows what they've been reading. On the contrary, 54 percent of librarians and 52.5 percent of students disagree or strongly disagree with that statement. Likewise, only 13.5 percent of librarians and 20.6 percent of students agree or strongly agree that they don't mind if people can view their personal information on the internet because they had nothing to hide; conversely, 78.3 percent of librarians and 68 percent of students disagree or strongly disagree with that statement.

On whether individuals must be duly notified by the library about any unauthorized access or breach of their personal information contained in library systems, 66.2 percent of librarians and 81.3 percent of students agree or strongly agree. Likewise, 70.2 percent of librarians and 77.8 percent of students agree or strongly agree that third-party firms must duly notify individuals about any unauthorized access or breach of their personal information contained in their systems. Also, 48.7 percent of librarians and 65.3 percent of students agree or strongly agree that individuals should be able to request and be given access to any personal data in the custody of the library, but 39.2 percent of librarians and 23.5 percent of students disagree or strongly disagree with this statement. Whereas 58.1 percent of librarians and 57 percent of students agree or strongly agree that individuals should be able to access any personal data held by social networking sites, 36.5 percent of librarians and 28.3 percent of students disagree or strongly disagree with this statement.

Finally, with respect to self-censoring their own search and reading habits to avoid being misunderstood, the responses among librarians were closely divided, with 27 percent saying they "Agree" or are "Neutral" on the practice; 24.3 percent said they disagree, 12.2 percent strongly agree, and 9.5 percent strongly disagree. For the students, the majority (32.2\%) were neutral on the practice, 29.3 percent agree, 16.7 percent disagree, 13.5 percent strongly agree, and 8.3 percent strongly disagree. This means that, while most of the librarians (39.2\%) and students (42.8\%) agree or strongly agree to self-censor their search and reading habits, still 
a significant number of them are neutral and disagree with the practice. This may be due to possible ambivalence toward online privacy issues among both categories of respondents.

\section{Privacy Concerns in Online Library Environments}

The results presented in table 6 (see appendices) provide additional information on privacy attitudes of respondents and indicate their level of concern on a range of online privacy issues. When asked if they were concerned about privacy while using the internet, nearly all the respondents ( $97.3 \%$ of librarians and $91.7 \%$ of students) indicated that they were very concerned or somewhat concerned. The results also show that 83.8 percent of librarians and 79.9 percent of students said they were very concerned or somewhat concerned about family, friends, and other acquaintances getting personal information about them and their web activities. Similarly, 85.1 percent of librarians and 83 percent of students were either very concerned or somewhat concerned about businesses and people whom they do not know getting personal information about them and their web activities. When asked about the government and law enforcement getting personal information about them and their web activities, 81.1 percent of librarians and 80 percent of students said they were either very concerned or somewhat concerned.

The analyses also show that most of the respondents $(87.8 \%$ of librarians and $89.8 \%$ of students) were very concerned or somewhat concerned about online identity theft. As expected, nearly all the respondents $(91.9 \%$ of librarians and $88.1 \%$ of students) said they were either very concerned or somewhat concerned about the security of personal information given to online companies. When asked whether they were concerned about providing too much personal information when joining a social networking site, most respondents ( $86.5 \%$ of librarians and $79.8 \%$ of students) said they were either very concerned or somewhat concerned. Most of the respondents ( $87.9 \%$ of librarians and $86.1 \%$ of students) indicated that they were very concerned or somewhat concerned about people they do not know obtaining personal information about them from their online activities. Likewise, 86.5 percent of librarians and 83.1 percent of students said they were very concerned or somewhat concerned about who might access their web browsing history from their computer. On how they feel about search engines tracking their keywords and sites visited, 75.7 percent of librarians and 81.7 percent of students indicated they were either very concerned or somewhat concerned.

Furthermore, a majority of the respondents ( $78.4 \%$ of librarians and $80.5 \%$ of students) said they were very concerned or somewhat concerned about the use of web cookies or other means of tracking their visits to other websites. Likewise, 82.4 percent of librarians and 80.4 percent of students indicated that they were very concerned or somewhat concerned about cell phone providers tracking their physical location. Similarly, when asked about how they feel about mobile and social networking applications collecting information about their activities online or physical location, 85.2 percent of librarians and 81.1 percent of students said they were either very concerned or somewhat concerned. Finally, 89.2 percent of librarians and 84.7 percent of students indicated that they were very concerned or somewhat concerned about other people uploading photos or videos of themselves to the internet where they are clearly recognizable without their permission.

When asked about how respondents felt about online sites tracking webpages they visited, 36.5 percent of librarians said they consider it to be harmful, 35.1 percent felt it was both beneficial and harmful, 16.2 percent felt it was beneficial, 4.1 percent felt it was neither beneficial nor harmful, and 8.1 percent said they did not know. For the students, 33.3 percent felt it was harmful, 31 percent said it was both beneficial and harmful, 11.2 percent felt it was 


\begin{tabular}{|c|c|c|c|c|c|c|c|}
\hline \multicolumn{8}{|c|}{$\begin{array}{c}\text { TABLE } 3 \\
\text { Online Tracking }\end{array}$} \\
\hline & & \multicolumn{2}{|c|}{ Librarians } & \multicolumn{2}{|c|}{ Students } & \multicolumn{2}{|c|}{ Total } \\
\hline & & $\mathbf{N}$ & $\%$ & $\mathbf{N}$ & $\%$ & $\mathbf{N}$ & $\%$ \\
\hline \multirow{6}{*}{$\begin{array}{l}\text { If an online site did track the } \\
\text { webpages you have visited, do you } \\
\text { think that would be... }\end{array}$} & beneficial to you & 12 & 16.2 & 81 & 11.2 & 93 & 11.6 \\
\hline & harmful to you & 27 & 36.5 & 242 & 33.3 & 269 & 33.6 \\
\hline & both & 26 & 35.1 & 225 & 31.0 & 251 & 31.4 \\
\hline & neither & 3 & 4.1 & 70 & 9.6 & 73 & 9.1 \\
\hline & don't know & 6 & 8.1 & 108 & 14.9 & 114 & 14.3 \\
\hline & Total & 74 & 100.0 & 726 & 100.0 & 800 & 100.0 \\
\hline
\end{tabular}

beneficial, 9.6 percent said it was neither beneficial nor harmful, and 14.9 percent said they don't know (see table 3).

\section{Response Patterns by Respondent Type}

We used the 5-point Likert scale to measure the respondents' privacy attitudes across 15 questions. Mann-Whitney U Test was run to determine whether there are significant differences in the ratings of privacy attitudes of librarians and students. With the significance level ( $p$-value) set at 0.05 , the analysis shows that there were significant differences in the response pattern for librarians and students in 5 of the 15 questions (see table 4); the null hypothesis for these

\begin{tabular}{|l|l|l|l|l|}
\hline \multicolumn{5}{|c|}{ Hypothesis Test Summary } \\
\hline 3 & $\begin{array}{l}\text { Null Hypothesis } \\
\text { The distribution of Libraries should never share personal } \\
\text { information, circulation records, or internet use records with } \\
\text { third parties unless it has been authorized by the individual } \\
\text { or by a court of law is the same across categories of } \\
\text { Respondent Type. }\end{array}$ & $\begin{array}{l}\text { Independent- } \\
\text { Samples Mann- } \\
\text { Whitney U Test }\end{array}$ & .009 & $\begin{array}{l}\text { Reject the null } \\
\text { hypothesis. }\end{array}$ \\
\hline 6 & $\begin{array}{l}\text { The distribution of Librarians should play a role in } \\
\text { educating students on the potential privacy rights risks } \\
\text { resulting from using the Internet (*) is the same across } \\
\text { categories of Respondent Type. }\end{array}$ & $\begin{array}{l}\text { Independent- } \\
\text { Samples Mann- } \\
\text { Whitney U Test }\end{array}$ & .018 & $\begin{array}{l}\text { Reject the null } \\
\text { hypothesis. }\end{array}$ \\
\hline 12 & $\begin{array}{l}\text { The distribution of Individuals must be duly notified by the } \\
\text { library about any unauthorized access or breach of their } \\
\text { personal information contained in library systems (+) is the } \\
\text { same across categories of Respondent Type. }\end{array}$ & $\begin{array}{l}\text { Independent- } \\
\text { Samples Mann- } \\
\text { Whitney U Test }\end{array}$ & .000 & $\begin{array}{l}\text { Reject the null } \\
\text { hypothesis. }\end{array}$ \\
\hline 13 & $\begin{array}{l}\text { The distribution of Third-party firms must duly notify } \\
\text { individuals about any unauthorized access or breach of } \\
\text { their personal information contained in their systems (+) is } \\
\text { the same across categories of Respondent Type. }\end{array}$ & $\begin{array}{l}\text { Independent- } \\
\text { Samples Mann- } \\
\text { Whitney U Test }\end{array}$ & .004 & $\begin{array}{l}\text { Reject the null } \\
\text { hypothesis. }\end{array}$ \\
\hline $\begin{array}{l}\text { The distribution of Individuals should be able to request for } \\
\text { and given access to any personal data in the custody of the } \\
\text { library (+) is the same across categories of Respondent Type. }\end{array}$ & $\begin{array}{l}\text { Independent- } \\
\text { Samples Mann- } \\
\text { Whitney U Test }\end{array}$ & .001 & $\begin{array}{l}\text { Reject the null } \\
\text { hypothesis. }\end{array}$ \\
\hline Asymptotic significances are displayed. The significance level is .05. & & & \\
\hline
\end{tabular}


questions is therefore rejected with $p<0.05$. Further comparison of the mean ranks shows that students were more likely to Agree or Strongly Agree with these questions than Librarians (see figures $1-5$ in appendices).

A four-point Likert scale was also used to measure the respondent's privacy concerns across 14 questions. Mann-Whitney $U$ Test shows no significant differences in the response pattern for librarians and students across all the questions. The null hypothesis for these questions is, therefore, retained with $p>0.05$.

\section{Discussion}

The use of licensed academic databases and the integration of social tools that can aggregate users' personal data and track online behaviors into libraries have enabled personalized service experiences but also present serious privacy consequences for both librarians and their patrons..$^{29}$ The growing concern for privacy and personal data security across the world has led to calls for stronger safeguards and legislations. ${ }^{30}$ Meanwhile, vendors are more likely to conform to information technology industry standards than those specific to libraries. ${ }^{31}$ The study investigated privacy attitudes and concerns within the Ghanaian academic library space and what the differences and similarities are for librarians and their student patrons.

It is argued that the development of legislative frameworks for privacy and personal data is typically influenced by globalization, emerging technologies, and the need to protect people against new business models that revolve around the use of personal data. ${ }^{32}$ As libraries are affected in many ways by these issues, studies (especially in the global north) have shown that privacy concerns are high among librarians and students who use library services. ${ }^{33}$ These sentiments are generally echoed here in Ghana with most librarians and students expressing high concerns about privacy generally and privacy issues within the library environment. The enactment of the Data Protection Act 2012 (Act 843) is largely indicative of the recognition of the growing individual concerns of information privacy and the implications of privacy violation and data breaches for Ghana. ${ }^{34}$

Major players in the Ghanaian academic library ecosystem want individuals to have greater control over their own personal data, just as expressed in Canada ${ }^{35}$ and the United States, ${ }^{36}$ and this probably explains why, overwhelmingly, they prefer that sharing decisions about personal information, circulation records, or internet use records are done with the individual's consent or when mandated by a court order. In contrast to the findings in the American and Canadian studies, however, far fewer Ghanaians believe that third-party firms are collecting too much personal information in the library environments with a drop in the response rates from 92.3 percent in Canada and 90 percent in the United States, respectively, to about 50 percent in Ghana. When combined with the fact that not many of our respondents believe that search engines are sharing their personal information and search records with companies, possible explanations for this low level of concern include the chance that respondents simply are less concerned about commercial data collection because they consider it necessary for personalized services experiences in the library, ${ }^{37}$ or it is due to a genuine lack of awareness about exactly how much information database providers or search engines are collecting about users and how they are used. This also explains why most of our respondents want search engine and social networking sites to prominently display policies on how users' information is treated.

Our respondents overwhelmingly also hold the view that, when they give consent to companies to use their personal data, the companies must solely use it for the purpose they 
consented to. This finding is also consistent with the findings in previous studies ${ }^{38}$ and places a call on academic libraries to protect the interest of their students by resisting contracts that incorporate "data use clauses that allow for broad capture and open-ended use of patron data and patron activity, or that are subject to change without notice." 39

The study also found that, overwhelmingly, librarians and students are concerned about their privacy in online environments. They do not want the government monitoring what they read and their web activities or people (whether relatives, just acquaintances or strangers) and businesses viewing and accessing their personal information online. Meanwhile, most of our respondents in both categories indicated either their neutrality or unamenability to selfcensoring their own search and reading habits to avoid being misunderstood - a possible sign of ambivalence toward online privacy issues. In addition, there was no consensus among both categories of respondents about any form of online tracking, although only a few of them think it is beneficial. Between those who think it was just harmful and those who think it was both beneficial and harmful, there is hardly any difference. If these opinions are indeed reflective of ambivalence, it gives credence to the arguments made about the privacy paradox. ${ }^{40}$

Though most of our respondents generally have a positive attitude about librarians' role in educating students on privacy issues, just a little more than half of them think that libraries are doing their best to prevent unauthorized access to their personal information and circulation records. While this feeling is very similar to the attitude of librarians in the Canadian study, it is at variance with the attitude of librarians in the American study. More importantly, this sentiment could signal two things: a possible decline in how much students trust the library to protect their interest and on the part of librarians, an indictment on their commitment to championing patron privacy and academic freedom. Librarians must see the trust their users (students) place in them as a privilege; to maintain this privilege, they need to be proactive in championing the cause of their students and facilitating privacy awareness within their institutions. ${ }^{41}$ On the basis of the near-unanimity of librarians and students on their privacy attitudes and concerns of the online library context, the hypothesis $\mathbf{H}_{\mathbf{1}}$ is confirmed.

Overall, privacy attitudes and concerns of academic librarians align with those of university students in Ghana; however, a few instances that show significant differences in the response pattern for their privacy attitudes is worth highlighting. The Mann-Whitney U Test shows that, compared to academic librarians, students were more likely to agree to the following statements: 1) "Libraries should never share personal information, circulation records, or Internet use records with third parties unless it has been authorized by the individual or by a court of law"; 2) "Librarians should play a role in educating students on the potential privacy rights risks resulting from using the Internet"; 3) "Individuals must be duly notified by the library about any unauthorized access or breach of their personal information contained in library systems"; 4) "Third-party firms must duly notify individuals about any unauthorized access or breach of their personal information contained in their systems"; and 5) "Individuals should be able to request for and given access to any personal data in the custody of the library." These revelations perhaps suggest a greater concern on these privacy issues among university students in Ghana, more so because it is their privacy and personal data at risk. Mimi Calter, Deputy University Librarian at Stanford and Chair of IFLA's Academic and Research Libraries Section, shares the same view noting that, while students are generally interested in protecting their own privacy, they mostly have little knowledge or influence on the terms negotiated for academic database licenses and management rights and have had to 
trust their librarians to protect their interests. ${ }^{42}$ The disparity in response pattern, however, is likely due to the balancing act required of librarians to effectively and innovatively use emerging technologies to deliver better service experiences for their patrons. ${ }^{43}$ Ghanaian academic librarians need to be proactive in educating and supporting students about privacy and making informed online decisions and encouraging them to be aware of the implications of privacy breaches and guidelines for data and privacy protections as proposed in the IFLA Statement on Privacy in the Library Environment. ${ }^{44}$ These notable findings and accompanying comments notwithstanding, we are unable to confirm hypothesis $\mathbf{H}_{\mathbf{0}}$.

\section{Conclusion}

The study examined librarians' and student users' attitudes, perceptions, and concerns on privacy issues in Ghanaian universities, with the aim of seeking a better alignment of the perspectives of these groups. Despite limitations in the research approach, which involved reliance on self-reported data and hence a need for a study that relies, additionally, on observed behaviors of stakeholders, this study achieves its goal nonetheless.

This goal was achieved by comparing data on librarians' attitudes and concerns to those of students in their universities. On the outcome of the first objective of the study, the findings point to both librarians and students in Ghanaian universities desiring greater control over their own personal data in the online library context while requiring ethical responsibility on the part of data-collecting online library agents. Regarding the second objective, librarians and students expressed concern on their privacy in online environments and are wary of state censorship and corporate monopoly over their personal data. However, despite librarians' and students' positive attitude about the strong role of librarians in guaranteeing their personal data, a significant number of them demonstrate little faith in librarians to actualize the protection of their personal data. Finally, on the question of alignment between librarians and students on the variables, privacy attitudes and concerns of academic librarians were noted to align with those of university students in Ghana. On the basis of these findings, it is recommended that Ghanaian academic librarians, as part of their educational efforts, integrate privacy education for their users including students emphasizing the need to make informed online decisions and exposing potential repercussions of their decisions while using online library and digital resources. Again, librarians must demonstrate explicitly that they are able to maintain the sanctity of the data of their users (students). Explicit expressions of librarians' readiness to protect users' data may be achieved through the development of data protection policies embedded in library ICT policies. Furthermore, librarians must be genuinely concerned about user concerns of their data and provide constant assurance of their readiness to prioritize user needs in facilitating access to digital and online information.

\section{Acknowledgments}

The authors would like to thank Emeritus Professor Peter G. Underwood for his valuable comments. We are also very grateful to Professor Michael Zimmer for giving us permission to adopt and adapt his instrument for our study. 


\section{Appendices}

\begin{tabular}{|c|c|c|c|c|c|c|c|}
\hline \multicolumn{8}{|c|}{$\begin{array}{c}\text { TABLE } 5 \\
\text { General Privacy Attitudes }\end{array}$} \\
\hline & & \multicolumn{2}{|c|}{ Librarians } & \multicolumn{2}{|c|}{ Students } & \multicolumn{2}{|c|}{ Total } \\
\hline & & $\mathbf{N}$ & $\%$ & $\mathbf{N}$ & $\%$ & $\mathbf{N}$ & $\%$ \\
\hline \multirow{6}{*}{$\begin{array}{l}\text { Individuals should be able to } \\
\text { control who sees their personal } \\
\text { information. }\end{array}$} & Strongly Disagree & 7 & 9.5 & 56 & 7.7 & 63 & 7.9 \\
\hline & Disagree & 8 & 10.8 & 24 & 3.3 & 32 & 4.0 \\
\hline & Neutral & 3 & 4.1 & 18 & 2.5 & 21 & 2.6 \\
\hline & Agree & 13 & 17.6 & 161 & 22.2 & 174 & 21.8 \\
\hline & Strongly Agree & 43 & 58.1 & 467 & 64.3 & 510 & 63.8 \\
\hline & Total & 74 & 100.0 & 726 & 100.0 & 800 & 100.0 \\
\hline \multirow{6}{*}{$\begin{array}{l}\text { I'm concerned that third-party } \\
\text { firms are collecting too much } \\
\text { personal information about me } \\
\text { and other individuals in online } \\
\text { library environments. }\left(^{*}\right)\end{array}$} & Strongly Disagree & 7 & 9.5 & 56 & 7.7 & 63 & 7.9 \\
\hline & Disagree & 10 & 13.5 & 113 & 15.6 & 123 & 15.4 \\
\hline & Neutral & 20 & 27.0 & 191 & 26.3 & 211 & 26.4 \\
\hline & Agree & 24 & 32.4 & 229 & 31.5 & 253 & 31.6 \\
\hline & Strongly Agree & 13 & 17.6 & 137 & 18.9 & 150 & 18.8 \\
\hline & Total & 74 & 100.0 & 726 & 100.0 & 800 & 100.0 \\
\hline \multirow{6}{*}{$\begin{array}{l}\text { Libraries should never share } \\
\text { personal information, circulation } \\
\text { records, or internet use records } \\
\text { with third parties unless it has } \\
\text { been authorized by the individual } \\
\text { or by a court of law. }\end{array}$} & Strongly Disagree & 9 & 12.2 & 43 & 5.9 & 52 & 6.5 \\
\hline & Disagree & 6 & 8.1 & 45 & 6.2 & 51 & 6.4 \\
\hline & Neutral & 6 & 8.1 & 51 & 7.0 & 57 & 7.1 \\
\hline & Agree & 23 & 31.1 & 185 & 25.5 & 208 & 26.0 \\
\hline & Strongly Agree & 30 & 40.5 & 402 & 55.4 & 432 & 54.0 \\
\hline & Total & 74 & 100.0 & 726 & 100.0 & 800 & 100.0 \\
\hline \multirow{6}{*}{$\begin{array}{l}\text { When people give personal } \\
\text { information to a company for a } \\
\text { specific purpose, the company } \\
\text { should only use the information } \\
\text { for that purpose. }\end{array}$} & Strongly Disagree & 4 & 5.4 & 30 & 4.1 & 34 & 4.3 \\
\hline & \begin{tabular}{|l|} 
Disagree \\
\end{tabular} & 7 & 9.5 & 34 & 4.7 & 41 & 5.1 \\
\hline & Neutral & 3 & 4.1 & 43 & 5.9 & 46 & 5.8 \\
\hline & Agree & 20 & 27.0 & 178 & 24.5 & 198 & 24.8 \\
\hline & Strongly Agree & 40 & 54.1 & 441 & 60.7 & 481 & 60.1 \\
\hline & Total & 74 & 100.0 & 726 & 100.0 & 800 & 100.0 \\
\hline \multirow{6}{*}{$\begin{array}{l}\text { Librarians are doing all they can } \\
\text { to prevent unauthorized access } \\
\text { to students' personal information } \\
\text { and circulation records. }\left({ }^{*}\right)\end{array}$} & Strongly Disagree & 7 & 9.5 & 33 & 4.5 & 40 & 5.0 \\
\hline & Disagree & 8 & 10.8 & 73 & 10.1 & 81 & 10.1 \\
\hline & Neutral & 20 & 27.0 & 225 & 31.0 & 245 & 30.6 \\
\hline & Agree & 20 & 27.0 & 251 & 34.6 & 271 & 33.9 \\
\hline & Strongly Agree & 19 & 25.7 & 144 & 19.8 & 163 & 20.4 \\
\hline & Total & 74 & 100.0 & 726 & 100.0 & 800 & 100.0 \\
\hline \multirow{6}{*}{$\begin{array}{l}\text { Librarians should play a role } \\
\text { in educating students on the } \\
\text { potential privacy rights risks } \\
\text { resulting from using the internet. } \\
\left({ }^{*}\right)\end{array}$} & Strongly Disagree & 6 & 8.1 & 25 & 3.4 & 31 & 3.9 \\
\hline & Disagree & 2 & 2.7 & 29 & 4.0 & 31 & 3.9 \\
\hline & Neutral & 9 & 12.2 & 64 & 8.8 & 73 & 9.1 \\
\hline & Agree & 29 & 39.2 & 232 & 32.0 & 261 & 32.6 \\
\hline & Strongly Agree & 28 & 37.8 & 376 & 51.8 & 404 & 50.5 \\
\hline & Total & 74 & 100.0 & 726 & 100.0 & 800 & 100.0 \\
\hline
\end{tabular}




\begin{tabular}{|c|c|c|c|c|c|c|c|}
\hline \multicolumn{8}{|c|}{$\begin{array}{c}\text { TABLE } 5 \\
\text { General Privacy Attitudes }\end{array}$} \\
\hline & & \multicolumn{2}{|c|}{ Librarians } & \multicolumn{2}{|c|}{ Students } & \multicolumn{2}{|c|}{ Total } \\
\hline & & $\mathbf{N}$ & $\%$ & $\mathbf{N}$ & $\%$ & $\mathbf{N}$ & $\%$ \\
\hline \multirow{6}{*}{$\begin{array}{l}\text { Search engines (like Google) } \\
\text { and social networking sites } \\
\text { (like Facebook, Twitter) should } \\
\text { prominently display policies } \\
\text { on how a user's information is } \\
\text { treated. }\left(^{*}\right)\end{array}$} & Strongly Disagree & 4 & 5.4 & 35 & 4.8 & 39 & 4.9 \\
\hline & Disagree & 8 & 10.8 & 39 & 5.4 & 47 & 5.9 \\
\hline & Neutral & 7 & 9.5 & 66 & 9.1 & 73 & 9.1 \\
\hline & Agree & 24 & 32.4 & 232 & 32.0 & 256 & 32.0 \\
\hline & Strongly Agree & 31 & 41.9 & 354 & 48.8 & 385 & 48.1 \\
\hline & Total & 74 & 100.0 & 726 & 100.0 & 800 & 100.0 \\
\hline \multirow{6}{*}{$\begin{array}{l}\text { I self-censor my search and } \\
\text { reading habits out of fear that my } \\
\text { records could be misunderstood. }\end{array}$} & Strongly Disagree & 7 & 9.5 & 60 & 8.3 & 67 & 8.4 \\
\hline & Disagree & 18 & 24.3 & 121 & 16.7 & 139 & 17.4 \\
\hline & Neutral & 20 & 27.0 & 234 & 32.2 & 254 & 31.8 \\
\hline & Agree & 20 & 27.0 & 213 & 29.3 & 233 & 29.1 \\
\hline & Strongly Agree & 9 & 12.2 & 98 & 13.5 & 107 & 13.4 \\
\hline & Total & 74 & 100.0 & 726 & 100.0 & 800 & 100.0 \\
\hline \multirow{6}{*}{$\begin{array}{l}\text { I'm concerned that search } \\
\text { engines are sharing my personal } \\
\text { information and search records } \\
\text { with companies. }\end{array}$} & Strongly Disagree & 8 & 10.8 & 67 & 9.2 & 75 & 9.4 \\
\hline & Disagree & 13 & 17.6 & 135 & 18.6 & 148 & 18.5 \\
\hline & \begin{tabular}{|l|} 
Neutral \\
\end{tabular} & 16 & 21.6 & 187 & 25.8 & 203 & 25.4 \\
\hline & \begin{tabular}{|l|} 
Agree \\
\end{tabular} & 23 & 31.1 & 178 & 24.5 & 201 & 25.1 \\
\hline & Strongly Agree & 14 & 18.9 & 159 & 21.9 & 173 & 21.6 \\
\hline & Total & 74 & 100.0 & 726 & 100.0 & 800 & 100.0 \\
\hline \multirow{6}{*}{$\begin{array}{l}\text { I don't mind if the government } \\
\text { knows what I've been reading. }\end{array}$} & Strongly Disagree & 20 & 27.0 & 203 & 28.0 & 223 & 27.9 \\
\hline & Disagree & 20 & 27.0 & 178 & 24.5 & 198 & 24.8 \\
\hline & Neutral & 20 & 27.0 & 116 & 16.0 & 136 & 17.0 \\
\hline & Agree & 10 & 13.5 & 138 & 19.0 & 148 & 18.5 \\
\hline & Strongly Agree & 4 & 5.4 & 91 & 12.5 & 95 & 11.9 \\
\hline & Total & 74 & 100.0 & 726 & 100.0 & 800 & 100.0 \\
\hline \multirow{6}{*}{$\begin{array}{l}\text { I don't mind if people can view } \\
\text { my personal information on the } \\
\text { internet. I have nothing to hide. }\end{array}$} & Strongly Disagree & 28 & 37.8 & 326 & 44.9 & 354 & 44.3 \\
\hline & Disagree & 30 & 40.5 & 168 & 23.1 & 198 & 24.8 \\
\hline & Neutral & 6 & 8.1 & 82 & 11.3 & 88 & 11.0 \\
\hline & Agree & 6 & 8.1 & 86 & 11.8 & 92 & 11.5 \\
\hline & Strongly Agree & 4 & 5.4 & 64 & 8.8 & 68 & 8.5 \\
\hline & Total & 74 & 100.0 & 726 & 100.0 & 800 & 100.0 \\
\hline \multirow{6}{*}{$\begin{array}{l}\text { Individuals must be duly } \\
\text { notified by the library about any } \\
\text { unauthorized access or breach } \\
\text { of their personal information } \\
\text { contained in library systems. (+) }\end{array}$} & Strongly Disagree & 8 & 10.8 & 39 & 5.4 & 47 & 5.9 \\
\hline & Disagree & 11 & 14.9 & 41 & 5.6 & 52 & 6.5 \\
\hline & Neutral & 6 & 8.1 & 56 & 7.7 & 62 & 7.8 \\
\hline & Agree & 25 & 33.8 & 209 & 28.8 & 234 & 29.3 \\
\hline & Strongly Agree & 24 & 32.4 & 381 & 52.5 & 405 & 50.6 \\
\hline & Total & 74 & 100.0 & 726 & 100.0 & 800 & 100.0 \\
\hline
\end{tabular}




\begin{tabular}{|c|c|c|c|c|c|c|c|}
\hline \multicolumn{8}{|c|}{$\begin{array}{c}\text { TABLE } 5 \\
\text { General Privacy Attitudes }\end{array}$} \\
\hline & & \multicolumn{2}{|c|}{ Librarians } & \multicolumn{2}{|c|}{ Students } & \multicolumn{2}{|c|}{ Total } \\
\hline & & $\mathbf{N}$ & $\%$ & $\mathbf{N}$ & $\%$ & $\mathbf{N}$ & $\%$ \\
\hline \multirow{6}{*}{$\begin{array}{l}\text { Third-party firms must duly } \\
\text { notify individuals about any } \\
\text { unauthorized access or breach } \\
\text { of their personal information } \\
\text { contained in their systems. (+) }\end{array}$} & Strongly Disagree & 4 & 5.4 & 47 & 6.5 & 51 & 6.4 \\
\hline & Disagree & 9 & 12.2 & 46 & 6.3 & 55 & 6.9 \\
\hline & \begin{tabular}{|l|} 
Neutral \\
\end{tabular} & 9 & 12.2 & 68 & 9.4 & 77 & 9.6 \\
\hline & \begin{tabular}{|l|} 
Agree \\
\end{tabular} & 32 & 43.2 & 225 & 31.0 & 257 & 32.1 \\
\hline & Strongly Agree & 20 & 27.0 & 340 & 46.8 & 360 & 45.0 \\
\hline & Total & 74 & 100.0 & 726 & 100.0 & 800 & 100.0 \\
\hline \multirow{6}{*}{$\begin{array}{l}\text { Individuals should be able to } \\
\text { request and be given access to } \\
\text { any personal data in the custody } \\
\text { of the library. (+) }\end{array}$} & Strongly Disagree & 20 & 27.0 & 93 & 12.8 & 113 & 14.1 \\
\hline & Disagree & 9 & 12.2 & 78 & 10.7 & 87 & 10.9 \\
\hline & Neutral & 9 & 12.2 & 81 & 11.2 & 90 & 11.3 \\
\hline & Agree & 19 & 25.7 & 216 & 29.8 & 235 & 29.4 \\
\hline & Strongly Agree & 17 & 23.0 & 258 & 35.5 & 275 & 34.4 \\
\hline & Total & 74 & 100.0 & 726 & 100.0 & 800 & 100.0 \\
\hline \multirow{6}{*}{$\begin{array}{l}\text { Individuals should be able to } \\
\text { access any personal data held by } \\
\text { social networking sites. }(+)\end{array}$} & Strongly Disagree & 16 & 21.6 & 118 & 16.3 & 134 & 16.8 \\
\hline & Disagree & 11 & 14.9 & 87 & 12.0 & 98 & 12.3 \\
\hline & Neutral & 4 & 5.4 & 107 & 14.7 & 111 & 13.9 \\
\hline & Agree & 21 & 28.4 & 184 & 25.3 & 205 & 25.6 \\
\hline & Strongly Agree & 22 & 29.7 & 230 & 31.7 & 252 & 31.5 \\
\hline & Total & 74 & 100.0 & 726 & 100.0 & 800 & 100.0 \\
\hline \multicolumn{8}{|c|}{$\begin{array}{c}\text { TABLE } 6 \\
\text { Privacy Concerns }\end{array}$} \\
\hline & & \multicolumn{2}{|c|}{ Librarians } & \multicolumn{2}{|c|}{ Students } & \multicolumn{2}{|c|}{ Total } \\
\hline & & $\mathbf{N}$ & $\%$ & $\mathbf{N}$ & $\%$ & $\mathbf{N}$ & $\%$ \\
\hline \multirow{5}{*}{$\begin{array}{l}\text { Are you concerned about } \\
\text { your privacy while using the } \\
\text { internet? }\left(^{*}\right)\end{array}$} & Very Concerned & 59 & 79.7 & 594 & 81.8 & 653 & 81.6 \\
\hline & Somewhat Concerned & 13 & 17.6 & 72 & 9.9 & 85 & 10.6 \\
\hline & Not Too Concerned & 2 & 2.7 & 40 & 5.5 & 42 & 5.3 \\
\hline & Not at All Concerned & 0 & 0.0 & 20 & 2.8 & 20 & 2.5 \\
\hline & Total & 74 & 100.0 & 726 & 100.0 & 800 & 100.0 \\
\hline \multirow{5}{*}{$\begin{array}{l}\text { Are you concerned about } \\
\text { family, friends, and people } \\
\text { whom you know getting } \\
\text { personal information about } \\
\text { you and your web activities? } \\
(*)\end{array}$} & Very Concerned & 46 & 62.2 & 408 & 56.2 & 454 & 56.8 \\
\hline & Somewhat Concerned & 16 & 21.6 & 172 & 23.7 & 188 & 23.5 \\
\hline & Not Too Concerned & 11 & 14.9 & 110 & 15.2 & 121 & 15.1 \\
\hline & Not at All Concerned & 1 & 1.4 & 36 & 5.0 & 37 & 4.6 \\
\hline & Total & 74 & 100.0 & 726 & 100.0 & 800 & 100.0 \\
\hline \multirow{5}{*}{$\begin{array}{l}\text { Are you concerned about } \\
\text { businesses and people whom } \\
\text { you do not know getting } \\
\text { personal information about } \\
\text { you and your web activities? } \\
(*)\end{array}$} & Very Concerned & 51 & 68.9 & 491 & 67.6 & 542 & 67.8 \\
\hline & Somewhat Concerned & 12 & 16.2 & 112 & 15.4 & 124 & 15.5 \\
\hline & Not Too Concerned & 7 & 9.5 & 78 & 10.7 & 85 & 10.6 \\
\hline & Not at All Concerned & 4 & 5.4 & 45 & 6.2 & 49 & 6.1 \\
\hline & Total & 74 & 100.0 & 726 & 100.0 & 800 & 100.0 \\
\hline
\end{tabular}




\begin{tabular}{|c|c|c|c|c|c|c|c|}
\hline \multicolumn{8}{|c|}{$\begin{array}{c}\text { TABLE } 6 \\
\text { Privacy Concerns }\end{array}$} \\
\hline & & \multicolumn{2}{|c|}{ Librarians } & \multicolumn{2}{|c|}{ Students } & \multicolumn{2}{|c|}{ Total } \\
\hline & & $\mathbf{N}$ & $\%$ & $\mathbf{N}$ & $\%$ & $\mathbf{N}$ & $\%$ \\
\hline \multirow{5}{*}{$\begin{array}{l}\text { Are you concerned about } \\
\text { the government and law } \\
\text { enforcement getting personal } \\
\text { information about you and } \\
\text { your web activities? }\left(^{*}\right)\end{array}$} & Very Concerned & 38 & 51.4 & 417 & 57.4 & 455 & 56.9 \\
\hline & Somewhat Concerned & 22 & 29.7 & 164 & 22.6 & 186 & 23.3 \\
\hline & Not Too Concerned & 11 & 14.9 & 89 & 12.3 & 100 & 12.5 \\
\hline & Not at All Concerned & 3 & 4.1 & 56 & 7.7 & 59 & 7.4 \\
\hline & Total & 74 & 100.0 & 726 & 100.0 & 800 & 100.0 \\
\hline \multirow{5}{*}{$\begin{array}{l}\text { Are you concerned about } \\
\text { online identity theft? }\end{array}$} & Very Concerned & 59 & 79.7 & 564 & 77.7 & 623 & 77.9 \\
\hline & Somewhat Concerned & 6 & 8.1 & 88 & 12.1 & 94 & 11.8 \\
\hline & Not Too Concerned & 7 & 9.5 & 41 & 5.6 & 48 & 6.0 \\
\hline & Not at All Concerned & 2 & 2.7 & 33 & 4.5 & 35 & 4.4 \\
\hline & \begin{tabular}{|l|} 
Total \\
\end{tabular} & 74 & 100.0 & 726 & 100.0 & 800 & 100.0 \\
\hline \multirow{5}{*}{$\begin{array}{l}\text { Are you concerned about the } \\
\text { security of your information } \\
\text { given to online companies? }\end{array}$} & Very Concerned & 54 & 73.0 & 521 & 71.8 & 575 & 71.9 \\
\hline & Somewhat Concerned & 14 & 18.9 & 118 & 16.3 & 132 & 16.5 \\
\hline & Not Too Concerned & 3 & 4.1 & 48 & 6.6 & 51 & 6.4 \\
\hline & Not at All Concerned & 3 & 4.1 & 39 & 5.4 & 42 & 5.3 \\
\hline & Total & 74 & 100.0 & 726 & 100.0 & 800 & 100.0 \\
\hline \multirow{5}{*}{$\begin{array}{l}\text { Are you concerned that } \\
\text { you are asked for too much } \\
\text { personal information when } \\
\text { you join a social networking } \\
\text { site? }\end{array}$} & Very Concerned & 44 & 59.5 & 416 & 57.3 & 460 & 57.5 \\
\hline & Somewhat Concerned & 20 & 27.0 & 163 & 22.5 & 183 & 22.9 \\
\hline & Not Too Concerned & 9 & 12.2 & 107 & 14.7 & 116 & 14.5 \\
\hline & Not at All Concerned & 1 & 1.4 & 40 & 5.5 & 41 & 5.1 \\
\hline & Total & 74 & 100.0 & 726 & 100.0 & 800 & 100.0 \\
\hline \multirow{5}{*}{$\begin{array}{l}\text { Are you concerned about } \\
\text { people you do not know } \\
\text { obtaining personal } \\
\text { information about you from } \\
\text { your online activities? }\end{array}$} & Very Concerned & 52 & 70.3 & 516 & 71.1 & 568 & 71.0 \\
\hline & Somewhat Concerned & 13 & 17.6 & 109 & 15.0 & 122 & 15.3 \\
\hline & Not Too Concerned & 6 & 8.1 & 61 & 8.4 & 67 & 8.4 \\
\hline & Not at All Concerned & 3 & 4.1 & 40 & 5.5 & 43 & 5.4 \\
\hline & Total & 74 & 100.0 & 726 & 100.0 & 800 & 100.0 \\
\hline \multirow{5}{*}{$\begin{array}{l}\text { Are you concerned about } \\
\text { who might access your web } \\
\text { browsing history from your } \\
\text { computer itself? }\end{array}$} & Very Concerned & 53 & 71.6 & 469 & 64.6 & 522 & 65.3 \\
\hline & Somewhat Concerned & 11 & 14.9 & 134 & 18.5 & 145 & 18.1 \\
\hline & Not Too Concerned & 8 & 10.8 & 83 & 11.4 & 91 & 11.4 \\
\hline & Not at All Concerned & 2 & 2.7 & 40 & 5.5 & 42 & 5.3 \\
\hline & Total & 74 & 100.0 & 726 & 100.0 & 800 & 100.0 \\
\hline \multirow{5}{*}{$\begin{array}{l}\text { Are you concerned about } \\
\text { search engines tracking your } \\
\text { keywords and sites you visit? }\end{array}$} & Very Concerned & 40 & 54.1 & 451 & 62.1 & 491 & 61.4 \\
\hline & Somewhat Concerned & 16 & 21.6 & 142 & 19.6 & 158 & 19.8 \\
\hline & Not Too Concerned & 11 & 14.9 & 77 & 10.6 & 88 & 11.0 \\
\hline & Not at All Concerned & 7 & 9.5 & 56 & 7.7 & 63 & 7.9 \\
\hline & Total & 74 & 100.0 & 726 & 100.0 & 800 & 100.0 \\
\hline
\end{tabular}




\begin{tabular}{|c|c|c|c|c|c|c|c|}
\hline \multicolumn{8}{|c|}{$\begin{array}{c}\text { TABLE } 6 \\
\text { Privacy Concerns }\end{array}$} \\
\hline & & \multicolumn{2}{|c|}{ Librarians } & \multicolumn{2}{|c|}{ Students } & \multicolumn{2}{|c|}{ Total } \\
\hline & & $\mathbf{N}$ & $\%$ & $\mathbf{N}$ & $\%$ & $\mathbf{N}$ & $\%$ \\
\hline \multirow{5}{*}{$\begin{array}{l}\text { Are you concerned about the } \\
\text { use of web cookies or other } \\
\text { means of tracking your visits to } \\
\text { other websites? }\end{array}$} & Very Concerned & 40 & 54.1 & 407 & 56.1 & 447 & 55.9 \\
\hline & Somewhat Concerned & 18 & 24.3 & 177 & 24.4 & 195 & 24.4 \\
\hline & Not Too Concerned & 10 & 13.5 & 97 & 13.4 & 107 & 13.4 \\
\hline & Not at All Concerned & 6 & 8.1 & 45 & 6.2 & 51 & 6.4 \\
\hline & Total & 74 & 100.0 & 726 & 100.0 & 800 & 100.0 \\
\hline \multirow{5}{*}{$\begin{array}{l}\text { Are you concerned that } \\
\text { cellphone providers might } \\
\text { track your physical location? }\end{array}$} & Very Concerned & 43 & 58.1 & 401 & 55.2 & 444 & 55.5 \\
\hline & Somewhat Concerned & 18 & 24.3 & 183 & 25.2 & 201 & 25.1 \\
\hline & Not Too Concerned & 9 & 12.2 & 92 & 12.7 & 101 & 12.6 \\
\hline & Not at All Concerned & 4 & 5.4 & 50 & 6.9 & 54 & 6.8 \\
\hline & Total & 74 & 100.0 & 726 & 100.0 & 800 & 100.0 \\
\hline \multirow{5}{*}{$\begin{array}{l}\text { Are you concerned that } \\
\text { mobile and social networking } \\
\text { applications might collect } \\
\text { information about your } \\
\text { activities online or your } \\
\text { physical location? }\end{array}$} & Very Concerned & 38 & 51.4 & 442 & 60.9 & 480 & 60.0 \\
\hline & Somewhat Concerned & 25 & 33.8 & 147 & 20.2 & 172 & 21.5 \\
\hline & Not Too Concerned & 9 & 12.2 & 98 & 13.5 & 107 & 13.4 \\
\hline & Not at All Concerned & 2 & 2.7 & 39 & 5.4 & 41 & 5.1 \\
\hline & Total & 74 & 100.0 & 726 & 100.0 & 800 & 100.0 \\
\hline \multirow{5}{*}{$\begin{array}{l}\text { Are you concerned about } \\
\text { other people uploading a } \\
\text { photo or video of yourself to } \\
\text { the internet where you are } \\
\text { clearly recognizable without } \\
\text { your permission? }\end{array}$} & Very Concerned & 53 & 71.6 & 519 & 71.5 & 572 & 71.5 \\
\hline & Somewhat Concerned & 13 & 17.6 & 96 & 13.2 & 109 & 13.6 \\
\hline & Not Too Concerned & 3 & 4.1 & 57 & 7.9 & 60 & 7.5 \\
\hline & Not at All Concerned & 5 & 6.8 & 54 & 7.4 & 59 & 7.4 \\
\hline & Total & 74 & 100.0 & 726 & 100.0 & 800 & 100.0 \\
\hline
\end{tabular}




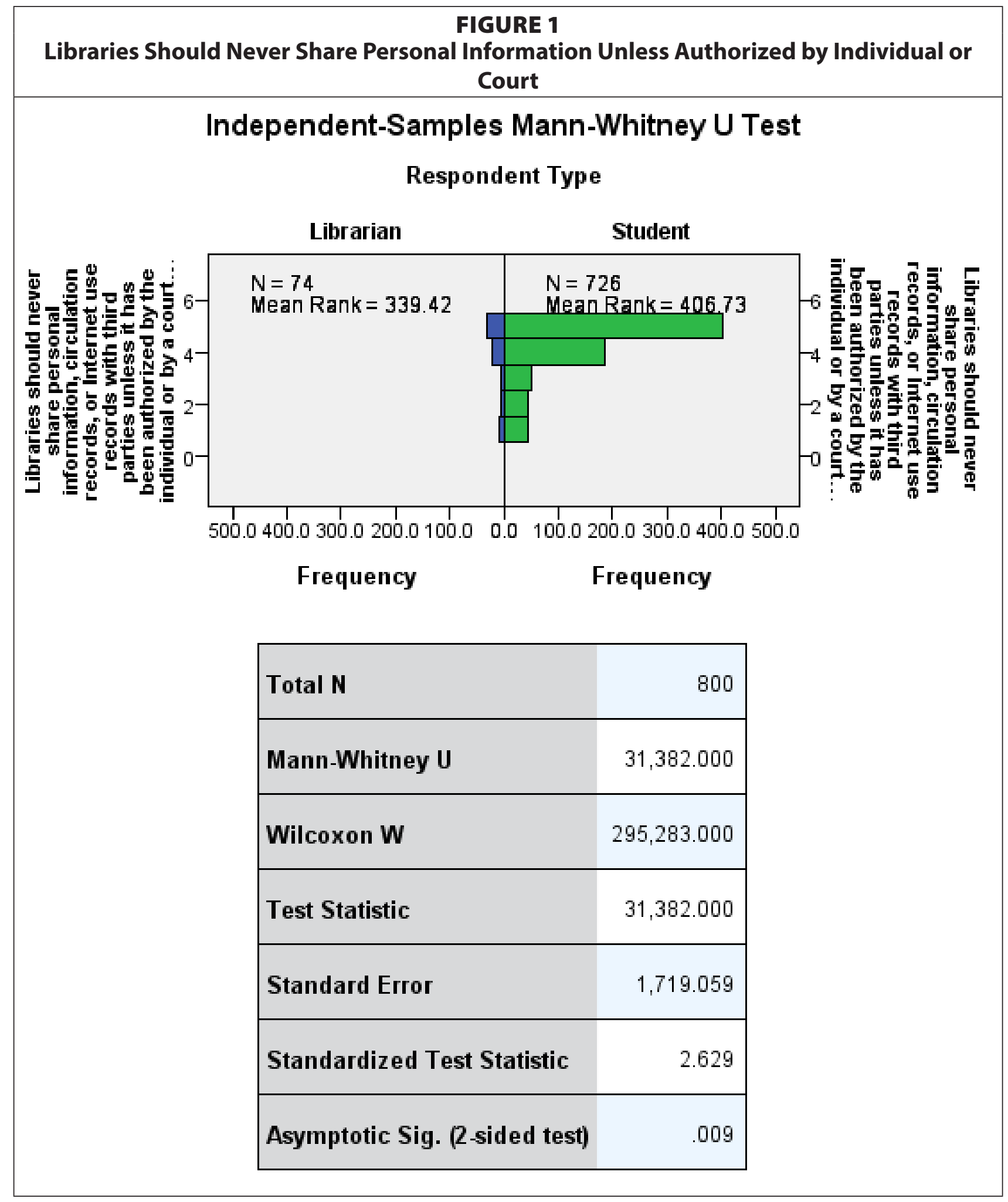




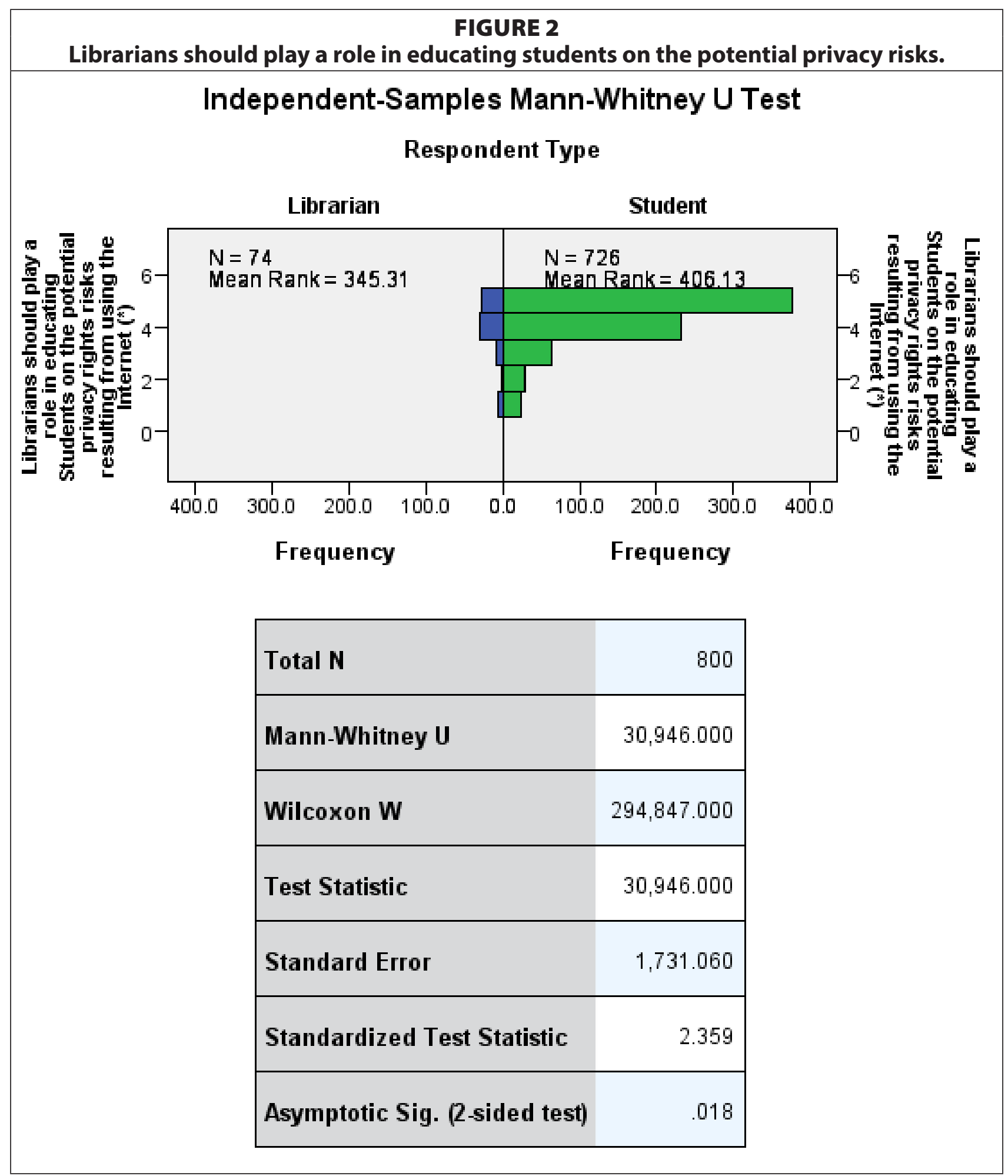




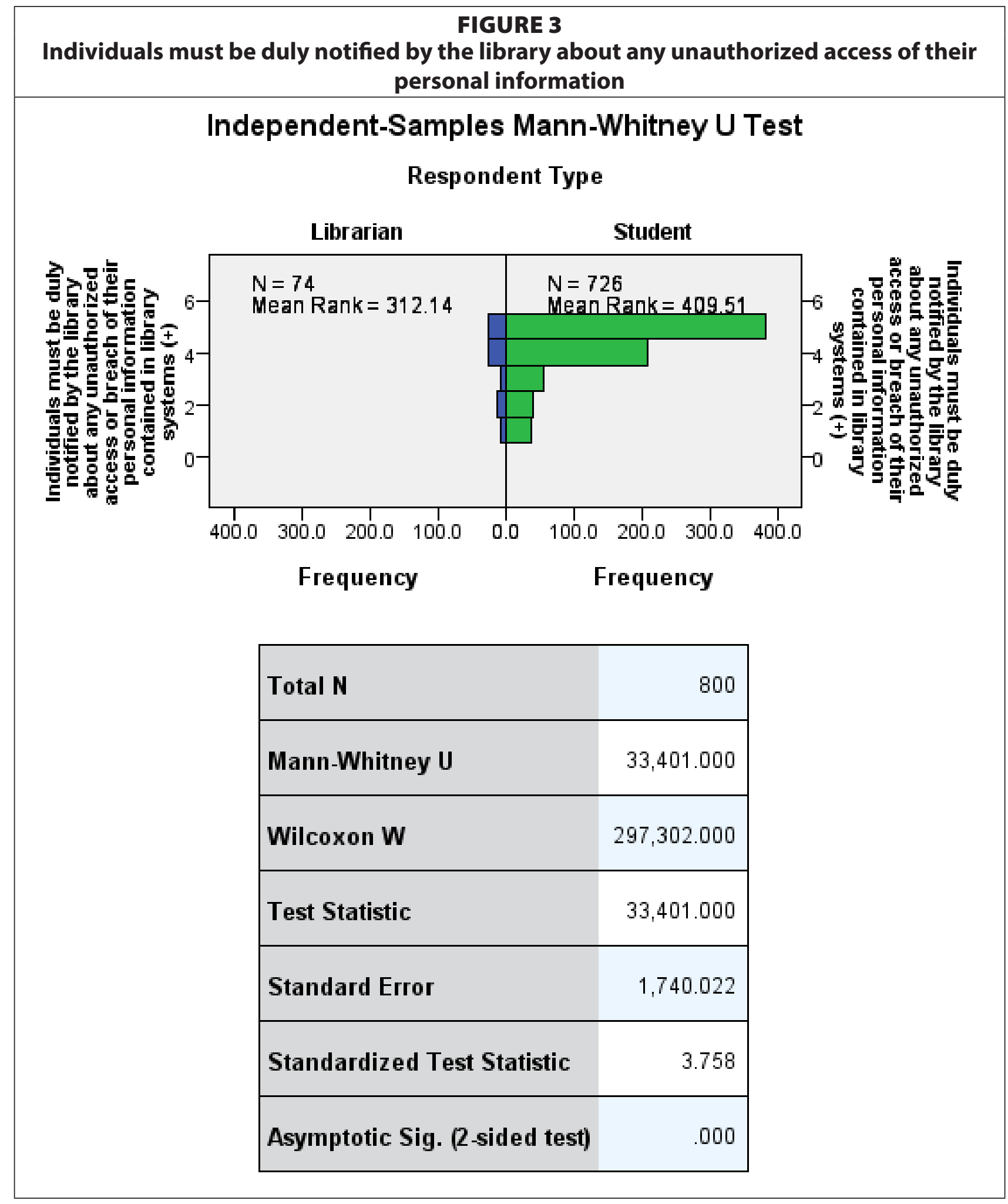




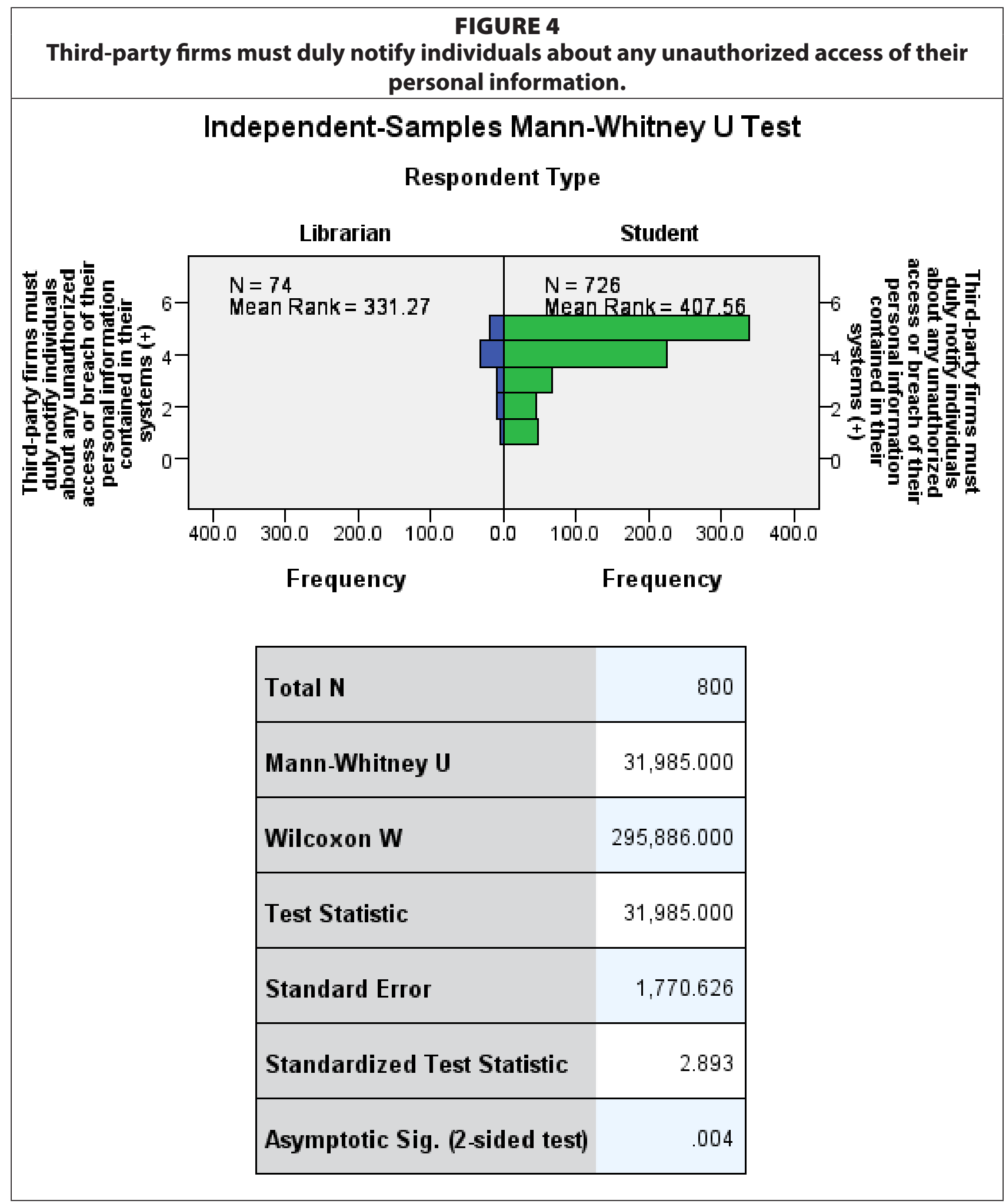




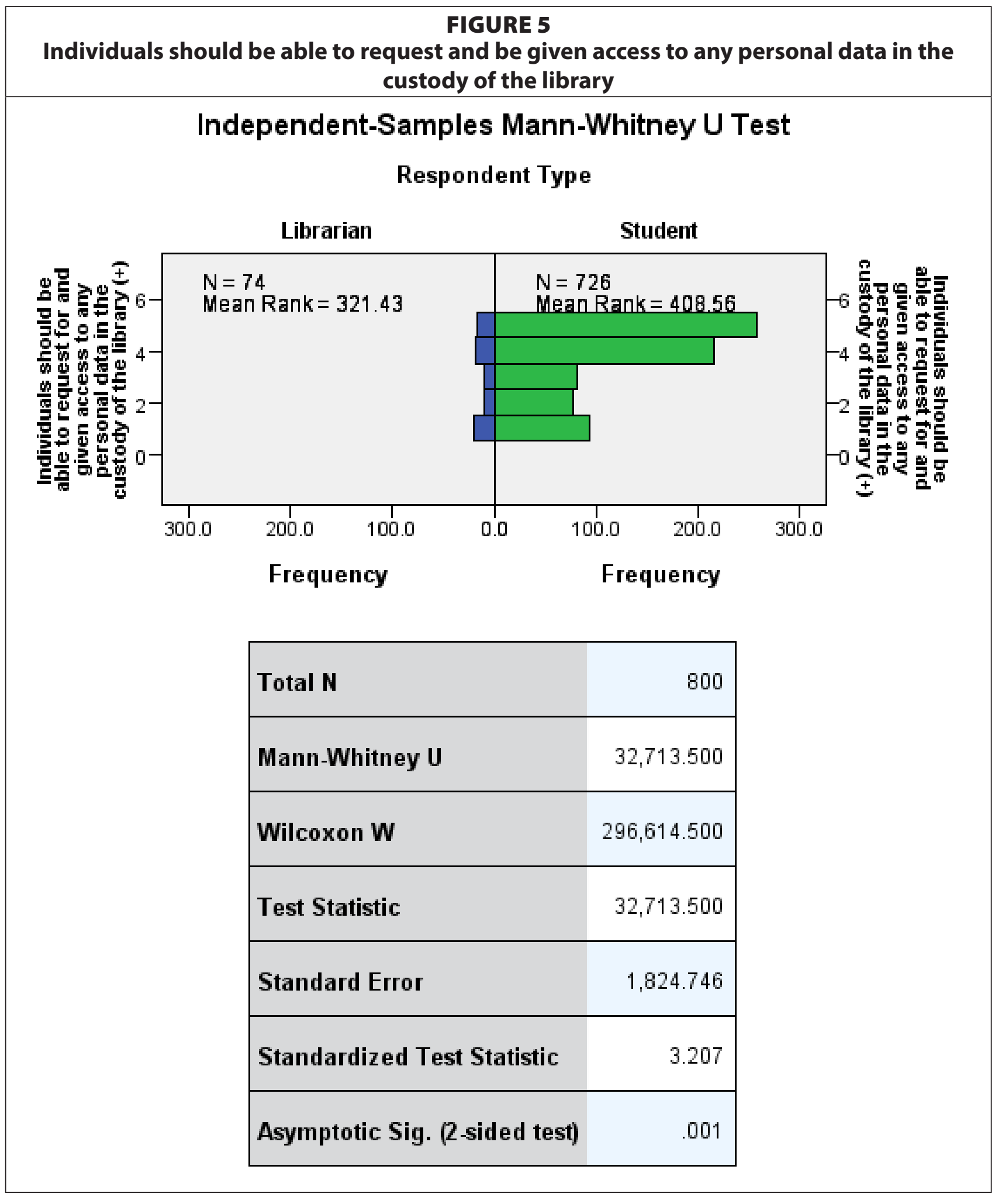

\section{Notes}

1. Michael Zimmer, "Librarians' Attitudes Regarding Information and Internet Privacy," Library Quarterly 84, no. 2 (2014): 123-51, https://doi.org/10.1086/675329.

2. Peter Fernandez, "Privacy and Generation Y: Applying Library Values to Social Networking Sites," Community \& Junior College Libraries 16, no. 2 (2010): 100-13, https://doi.org/10.1080/02763911003689495. 
3. Stephanie Krueger, "Academic Librarians in Canada Concerned about Online and Patron Privacy but Lack Knowledge about Institutional Procedures and Policies," Evidence Based Library and Information Practice 14, no. 2 (2019): 116-18, https://doi.org/10.18438/eblip29555.

4. Meredith G. Farkas, “Technology in Practice: Too Much Information?" American Libraries 42, no. 5/6 (2011): 36, http://archives.pdx.edu/ds/psu/7308; Judith Fingeret Krug and Candace D. Morgan, "ALA and Intellectual Freedom: A Historical Overview," in Intellectual Freedom Manual, 8th ed. (Chicago, IL: American Library Association, 2010), 21-36; Barbara M. Jones, Protecting Intellectual Freedom in Your Academic Library (Chicago, IL: American Library Association, 2009).

5. Shana Ponelis, "Ethical Risks of Social Media Use by Academic Libraries," Innovation: Journal of Appropriate Librarianship and Information Work in Southern Africa 2013, no. 47 (2013): 231-44, https://hdl.handle.net/10520/EJC158314.

6. Michael Zimmer, "Assessing the Treatment of Patron Privacy in Library 2.0 Literature," Information Technology and Libraries 32, no. 2 (October 2, 2013): 29-41, https://doi.org/10.6017/ital.v32i2.3420.

7. David McMenemy, "Rights to Privacy and Freedom of Expression in Public Libraries: Squaring the Circle," in IFLA World Library and Information Congress (Greater Columbus Convention Center, 2016), 1-9, https:// strathprints.strath.ac.uk/57407/; Alan Rubel, “Libraries, Electronic Resources, and Privacy: The Case for Positive Intellectual Freedom," Library Quarterly 84, no. 2 (October 2, 2014): 183-208, https://doi.org/10.1086/675331; John W.W. Cyrus and Mark P. Baggett, "Mobile Technology: Implications for Privacy and Librarianship," Reference Librarian 53, no. 3 (2012): 284-96, https://doi.org/10.1080/02763877.2012.678765.

8. Nikki Tummon and Dawn McKinnon, "Attitudes and Practices of Canadian Academic Librarians Regarding Library and Online Privacy: A National Study," Library \& Information Science Research 40, no. 2 (2018): 86-97, https://doi.org/10.1016/j.lisr.2018.05.002.

9. Kelley Cotter and Maureen Diana Sasso, “Libraries Protecting Privacy on Social Media: Sharing without 'Oversharing,'” Pennsylvania Libraries: Research \& Practice 4, no. 2 (2016): 73-90, https://doi.org/10.5195/palrap.2016.130.

10. Martyn Wade, "Privacy and Libraries," in IFLA World Library and Information Congress (Cape Town, South Africa, 2015), 1-7, http://library.ifla.org/1264/1/113-wade-en.pdf.

11. Zimmer, "Assessing the Treatment of Patron Privacy in Library 2.0 Literature"; Jill M. Sodt and Terri Pedersen Summey, "Beyond the Library's Walls: Using Library 2.0 Tools to Reach Out to All Users," Journal of Library Administration 49, no. 1/2 (2009): 97-109, https://doi.org/10.1080/01930820802312854.

12. Masoumeh Ansari et al., "The Role of Social Networks in the Scientific Exchange of Librarians: A Case Study," Library Philosophy \& Practice, 2018, 1-16, https://digitalcommons.unl.edu/libphilprac/1837; Viscount Buernortey Buer, Christopher Mfum Owusu-Ansah, and Gabriel Kwesi Acquah, "Facebook Use among Students of University of Education Winneba, Ghana," Ghana Library Journal 26, no. 2 (2016): 65-79; Christopher OwusuAnsah et al., "Applications of Social Media and Web 2.0 for Research Support in Selected African Academic Institutions," Journal of Balkan Libraries Union 3, no. 1 (2015): 30-39, https://doi.org/10.16918/bluj.77572; Tom Kwanya, Christine Stilwell, and Peter G. Underwood, "Intelligent Libraries and Apomediators: Distinguishing between Library 3.0 and Library 2.0," Journal of Librarianship and Information Science 45, no. 3 (2013): 187-97, https://doi. org/10.1177/0961000611435256; Efua Mansa Ayiah and Cynthia Henewaa Kumah, "Social Networking: A Tool to Use for Effective Service Delivery to Clients by African Libraries," in World Library and Information Congress: 77th IFLA General Conference and Assembly (San Juan, Puerto Rico, 2011), 1-14, https://cf5-www.ifla.org/pastwlic/2011/183-ayiah-en.pdf.

13. Tummon and McKinnon, "Attitudes and Practices of Canadian Academic Librarians Regarding Library and Online Privacy"; Cotter and Sasso, "Libraries Protecting Privacy on Social Media"; Ponelis, "Ethical Risks of Social Media Use by Academic Libraries"; Zimmer, "Assessing the Treatment of Patron Privacy in Library 2.0 Literature."

14. Cotter and Sasso, "Libraries Protecting Privacy on Social Media"; Ponelis, "Ethical Risks of Social Media Use by Academic Libraries."

15. Cotter and Sasso, "Libraries Protecting Privacy on Social Media," 75.

16. Ponelis, "Ethical Risks of Social Media Use by Academic Libraries."

17. Cherie L. Givens, Information Privacy Fundamentals for Librarians and Information Professionals (Lanham, MD: Rowman \& Littlefield, 2014), 24.

18. Tummon and McKinnon, "Attitudes and Practices of Canadian Academic Librarians Regarding Library and Online Privacy"; Zimmer, "Librarians' Attitudes Regarding Information and Internet Privacy"; Steven Johns and Karen Lawson, "University Undergraduate Students and Library-Related Privacy Issues," Library $\mathcal{E}$ Information Science Research 27, no. 4 (2005): 485-95, https://doi.org/10.1016/j.lisr.2005.08.006.

19. Farkas, "Technology in Practice: Too Much Information?"

20. Krueger, "Academic Librarians in Canada Concerned about Online and Patron Privacy but Lack Knowledge about Institutional Procedures and Policies"; Tummon and McKinnon, "Attitudes and Practices of Canadian Academic Librarians Regarding Library and Online Privacy." 
21. Johns and Lawson, "University Undergraduate Students and Library-Related Privacy Issues."

22. Lynne Siemens, "Balancing Students' Privacy Concerns While Increasing Student Engagement in ELearning Environments," in Increasing Student Engagement and Retention in E-Learning Environments: Web 2.0 and Blended Learning Technologies, Catherine Althaus, Charles Wankel, and Patrick Blessinger, eds., vol. 6, Part G, Cutting-Edge Technologies in Higher Education (Bingley, UK: Emerald Group Publishing Limited, 2013), 339-57, https://doi.org/10.1108/S2044-9968(2013)000006G014.

23. Susanne Barth and Menno D.T. de Jong, "The Privacy Paradox: Investigating Discrepancies between Expressed Privacy Concerns and Actual Online Behavior: A Systematic Literature Review," Telematics and Informatics 34, no. 7 (2017): 1038-58, https://doi.org/10.1016/j.tele.2017.04.013; Patricia A. Norberg, Daniel R. Horne, and David A. Horne, "The Privacy Paradox: Personal Information Disclosure Intentions versus Behaviors," Journal of Consumer Affairs 41, no. 1 (2007): 100-26, https://doi.org/10.1111/j.1745-6606.2006.00070.x; Susan B. Barnes, "A Privacy Paradox: Social Networking in the United States," First Monday 11, no. 9 (2006), https://doi.org/10.5210/fm.v11i9.1394.

24. Tummon and McKinnon, "Attitudes and Practices of Canadian Academic Librarians Regarding Library and Online Privacy"; Zimmer, "Librarians' Attitudes Regarding Information and Internet Privacy."

25. Johns and Lawson, "University Undergraduate Students and Library-Related Privacy Issues."

26. Margo Jeske et al., "The Intersection of Freedom of Information, Privacy Legislation and Library Services in Canadian Jurisdictions," Legal Information Management 16, no. 1 (2016): 14-21, https://doi.org/10.1017/S1472669616000050.

27. Tummon and McKinnon, "Attitudes and Practices of Canadian Academic Librarians Regarding Library and Online Privacy."

28. Zimmer, "Librarians' Attitudes Regarding Information and Internet Privacy."

29. Zimmer, "Assessing the Treatment of Patron Privacy in Library 2.0 Literature"; Sodt and Summey, "Beyond the Library's Walls"; Tummon and McKinnon, "Attitudes and Practices of Canadian Academic Librarians Regarding Library and Online Privacy"; Cotter and Sasso, "Libraries Protecting Privacy on Social Media"; Jeske et al., "The Intersection of Freedom of Information, Privacy Legislation and Library Services in Canadian Jurisdictions"; Ponelis, "Ethical Risks of Social Media Use by Academic Libraries."

30. Jeske et al., "The Intersection of Freedom of Information, Privacy Legislation and Library Services in Canadian Jurisdictions"; Jones, Protecting Intellectual Freedom in Your Academic Library.

31. April D. Lambert, Michelle Parker, and Masooda Bashir, "Library Patron Privacy in Jeopardy: An Analysis of the Privacy Policies of Digital Content Vendors," in Proceedings of the 78th ASISET Annual Meeting: Information Science with Impact: Research in and for the Community (St. Louis, MO: American Society for Information Science, 2015), 1-9, https://dl.acm.org/citation.cfm?id=2857114.

32. Dominic N. Dagbanja, "The Right to Privacy and Data Protection in Ghana," in African Data Privacy Laws, Alex B Makulilo, ed., Law, Governance and Technology Series (Cham, Switzerland: Springer, 2016), 230, https:// doi.org/10.1007/978-3-319-47317-8_10.

33. Tummon and McKinnon, "Attitudes and Practices of Canadian Academic Librarians Regarding Library and Online Privacy"; Zimmer, "Librarians' Attitudes Regarding Information and Internet Privacy"; Johns and Lawson, "University Undergraduate Students and Library-Related Privacy Issues."

34. Dagbanja, "The Right to Privacy and Data Protection in Ghana," 232.

35. Tummon and McKinnon, "Attitudes and Practices of Canadian Academic Librarians Regarding Library and Online Privacy."

36. Zimmer, "Librarians' Attitudes Regarding Information and Internet Privacy."

37. Zimmer, "Librarians' Attitudes Regarding Information and Internet Privacy."

38. Tummon and McKinnon, "Attitudes and Practices of Canadian Academic Librarians Regarding Library and Online Privacy"; Zimmer, "Librarians' Attitudes Regarding Information and Internet Privacy"; Siemens, "Balancing Students' Privacy Concerns While Increasing Student Engagement in E-Learning Environments"; Johns and Lawson, "University Undergraduate Students and Library-Related Privacy Issues."

39. IFLA, "Protecting Privacy in the Modern Academic Library: An Interview with Mimi Calter," 2019, https:/ www.ifla.org/node/92094.

40. Barth and de Jong, "The Privacy Paradox"; Norberg, Horne, and Horne, "The Privacy Paradox"; Barnes, "A Privacy Paradox."

41. Lisa Sutlieff and Jackie Chelin, "'An Absolute Prerequisite': The Importance of User Privacy and Trust in Maintaining Academic Freedom at the Library," Journal of Librarianship and Information Science 42, no. 3 (October 2, 2010): 163-77, https://doi.org/10.1177/0961000610368916.

42. IFLA, "Protecting Privacy in the Modern Academic Library: An Interview with Mimi Calter."

43. Tummon and McKinnon, "Attitudes and Practices of Canadian Academic Librarians Regarding Library and Online Privacy."

44. IFLA, "IFLA Statement on Privacy in the Library Environment," 2015, https://www.ifla.org/publications/node/10056. 